\title{
CORROSION OF GALVANIZED STEEL IN VARIOUS AQUEOUS ENVIRONMENTS PRESENT IN NATURE
}

\author{
Tamara RADU \\ "Dunarea de Jos" University of Galati, Romania \\ e-mail: tradu@ugal.ro
}

\begin{abstract}
Experimental research has focused on the corrosion behaviour of a widely used protective coating, respectively, galvanized sheet in various corrosive aqueous environments present in nature. In the laboratory experiments, the following were chosen as corrosive media: rainwater, domestic water, Danube water and sea water.

Galvanized sheet can interact with these environments due to its use in metal constructions, home appliances, car construction, food industry, others.

In order to assess the corrosion resistance, the mass loss was determined for a period of five weeks. The results showed a higher corrosion rate in rainwater compared to the other corrosive environments tested. The lowest corrosion rate was in sea water. In domestic water and Danube water the mass loss was comparable.
\end{abstract}

KEYWORDS: galvanized sheet, corrosion, rainwater, domestic water, Danube water

\section{Introduction}

Galvanized sheet is a product widely used in various fields such as construction, home appliances, car construction, food industry, others [1].

The corrosion resistance of the galvanized sheet is influenced by the following factors: the thickness of the zinc layer, the quality, purity and adhesion of the zinc layer, the composition of the corrosive environment [2].
Zinc corrosion is best controlled in the $\mathrm{pH}$ range of 5.5 to 12 and zinc can provide the steel protection for up to 25 years in rural areas and 5-12 years in urban areas [3, 4].

EN ISO 12944-2 specifies five categories of corrosion resistance (C1 to C5) for hot dip galvanized steel.

Table 1 presents the characteristics of these categories regarding the loss of mass and the reduction of the layer thickness at a one-year exposure to various corrosive atmospheric conditions [5].

Table 1. Atmospheric corrosivity categories s of typical environments

\begin{tabular}{|c|c|c|c|c|c|}
\hline $\begin{array}{c}\text { Corrosion } \\
\text { category }\end{array}$ & $\begin{array}{c}\text { C1 } \\
\text { very low }\end{array}$ & $\begin{array}{c}\text { C2 } \\
\text { low }\end{array}$ & $\begin{array}{c}\text { C3 } \\
\text { middle }\end{array}$ & $\begin{array}{c}\text { C4 } \\
\text { hig }\end{array}$ & $\begin{array}{c}\text { C5 } \\
\text { very hig }\end{array}$ \\
\hline $\begin{array}{c}\text { Zinc mass loss } \\
{\left[\mathrm{g} / \mathrm{m}^{2} \text { year] }\right.}\end{array}$ & $<0.7$ & $>0.7-5$ & $>5-15$ & $>15-30$ & $>30-60$ \\
\hline $\begin{array}{c}\text { Thickness reduction } \\
{[\mu \mathrm{m} / \text { year] }}\end{array}$ & $<0.1$ & $>0.1-0.7$ & $>0.7-2.1$ & $>2.1-4.2$ & $>4.2-8.4$ \\
\hline $\begin{array}{c}\text { Corrosive } \\
\text { environments }\end{array}$ & $\begin{array}{c}\text { Rural } \\
\text { areas }\end{array}$ & $\begin{array}{c}\text { Atmospheres } \\
\text { with low } \\
\text { level of } \\
\text { pollution }\end{array}$ & $\begin{array}{c}\text { Urban and industrial } \\
\text { atmospheres, } \\
\text { moderate sulfur dioxide } \\
\text { pollution. Coastal areas } \\
\text { with low salinity }\end{array}$ & $\begin{array}{c}\text { Industrial } \\
\text { areas and } \\
\text { coastal areas } \\
\text { with moderate } \\
\text { salinity }\end{array}$ & $\begin{array}{c}\text { Industrial areas } \\
\text { with high } \\
\text { humidity and } \\
\text { aggressive } \\
\text { atmosphere }\end{array}$ \\
\hline
\end{tabular}


The corrosion behaviour of galvanized steel in aqueous media, under conditions of immersion or exposure, is a less generalized case [6]. Moisture is highly corrosive to most metals, including steel and zinc [7].
EN ISO 12944-2 also contains three categories of corrosion for galvanized steel structures immersed in water (IM1, IM2) or buried in the ground (IM3) but no concrete values are indicated for mass loss (Table 2) [6].

Table 2. Corrosion category for water and soil

\begin{tabular}{|c|c|c|}
\hline $\begin{array}{c}\text { Corrosion } \\
\text { category }\end{array}$ & $\begin{array}{c}\text { Corrosion } \\
\text { environment }\end{array}$ & $\begin{array}{c}\text { Examples of environments and } \\
\text { structures }\end{array}$ \\
\hline IM1 & Fresh water & $\begin{array}{c}\text { River installations, hydro-electric power } \\
\text { plants }\end{array}$ \\
\hline IM2 & Sea or brackish water & $\begin{array}{c}\text { Harbor areas with structures like sluice } \\
\text { gates, locks, jetties; offshore structures } \\
\text { Buried tanks, steel piles, steel pipes }\end{array}$ \\
\hline
\end{tabular}

Many parameters affect the corrosion of zinc in a water environment, such as $\mathrm{pH}$, oxygen content, water temperature and other chemicals and dissolved elements.

For example, in distilled water, zinc may have a low corrosion rate, provided it is free of oxygen and carbon dioxide. Freshwater environments have a major component for classifying the corrosion potential respectively water hardness. Zinc is more resistant to hard water than water with low hardness.

Sea water has, at surface, $\mathrm{pH}$ of 8 due to excessive amounts of carbonates and the $\mathrm{pH}$ can drop to 7 in stagnant water. Also, the depth of the water has an influence on the $\mathrm{pH}$ level. Sea water temperature can vary greatly from negative values at the poles to $35^{\circ} \mathrm{C}$ at the equator. The higher the temperature, the higher the corrosion of the zinc layer in the water. Tides and waves are also important considerations in determining the corrosion protection provided by galvanized steel $[8,9]$.

Determining the corrosion rate of zinc in water thus becomes a particular step necessary to assess the durability of galvanized products when used in an aqueous corrosive environment.

The present paper makes an analysis of the behaviour of galvanized sheet in rainwater, domestic water, sea water and Danube water, with the determination of mass loss in a period of five weeks.

\section{Experimental research}

The experimental researches aimed at the corrosion behaviour of some samples of hot-dip galvanized sheet with a layer thickness of $60 \mathrm{~g} / \mathrm{m}^{2}$ in four corrosive environments: rainwater, domestic water, Danube water and sea water.

Sea water was prepared in the laboratory and rainwater, domestic water and Danube water were collected from the environment.

The corrosion behaviour was assessed by determining the gravimetric index $\left(\mathrm{I}_{\mathrm{g}}\right)$, respectively the mass loss, depending on the surface of the sample and the number of hours in which it was immersed in the corrosive environment [10].

$$
\mathrm{I}_{\mathrm{g}}=\mathrm{m}_{0}-\mathrm{m}_{1} / 2 \mathrm{St}\left[\mathrm{g} / \mathrm{m}^{2} \mathrm{~h}\right]
$$

where:

$\mathrm{m}_{0}=$ initial mass of the sample;

$\mathrm{m}_{1}=$ mass of the sample after one week in a corrosive environment;

$\mathrm{S}=$ surface of the sample;

$\mathrm{t}=$ time.

The samples were individually immersed in separate containers containing the corrosive media tested. The testing was done at ambient temperature, static.

The samples were tested for 5 weeks, i.e. a number of 840 hours, with the measurement of mass variation every 7 days.

\subsection{Behaviour of galvanized sheet in Danube water}

Water was collected from the Danube River in the area of Galati. It was used after settling the impurities and had a $\mathrm{pH}$ of 8.71. Zinc corrosion in freshwater, such as Danube water, is a complex process largely controlled by water impurities [6].

Figure 1 shows the Ig variation for the analysed period. A close value of the gravimeter index is observed during the experiment except for the first week when the weight loss is lower.

Figure 2 shows the corrosion rate every week. It is observed that the corrosion rate is different depending on the analysed week, so in the second week the samples corrode at high speed, and in the next two weeks, the corrosion rate decreases substantially. The phenomenon is explained by the formation in the first two weeks of adherent corrosion products which does not clean off by applied 
washing, which ensures a passivation of the surface for the following weeks and a reduction of the corrosion rate to about one third. In the fifth week the corrosion rate increases again.

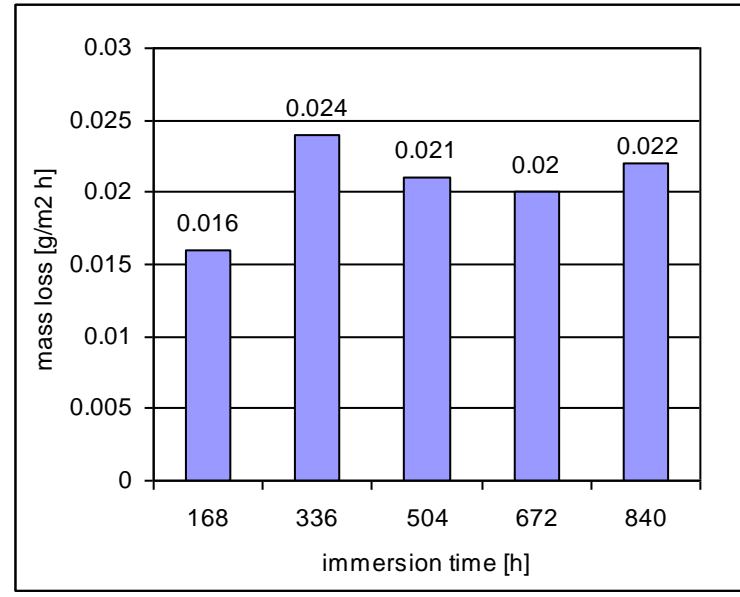

Fig. 1. Mass loss in Danube water in time

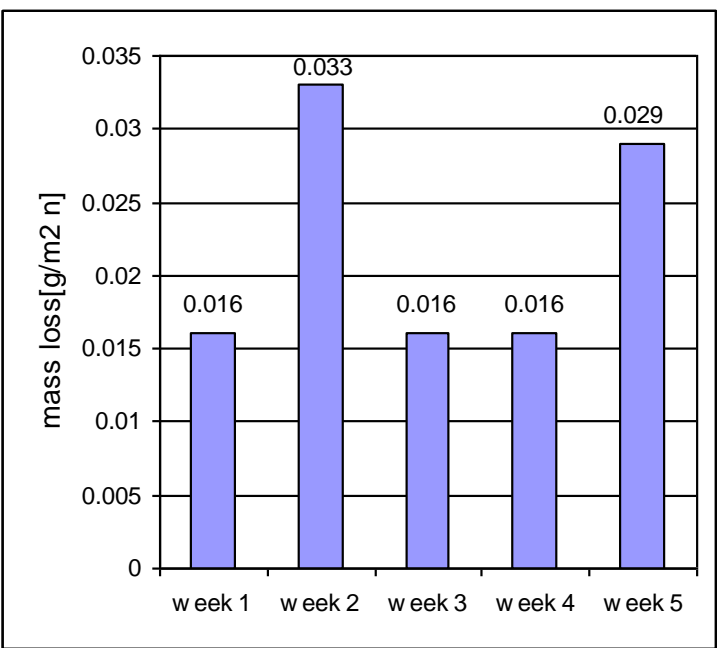

Fig. 2. Weekly mass loss in Danube water

\subsection{Behaviour of galvanized sheet in rainwater}

The rainwater had a $\mathrm{pH}$ of 7.04 . Figure 3 shows the mass loss depending on the duration of the corrosion process in rainwater.

As can be seen and in Fig. 4, the highest corrosion rate is recorded in the first week (after 168 h). Continued maintenance of the galvanized sheet in the corrosive environment leads to a substantial decrease in the corrosion rate with a relatively constant maintenance over the next 4 weeks. However, we must keep in mind that, in practice, the galvanized sheet will be in contact with rainwater for a small number of hours and the exposure will be periodic. Rainwater is very corrosive to zinc coatings due to the presence of dissolved oxygen and carbon dioxide. Oxygen dissolved in pure water is five to ten times more aggressive than carbonic acid [6].

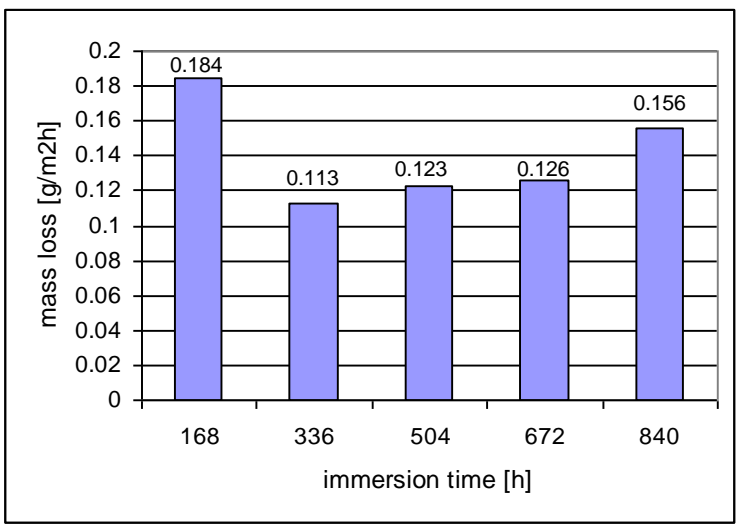

Fig. 3. Mass loss in rainwater in time

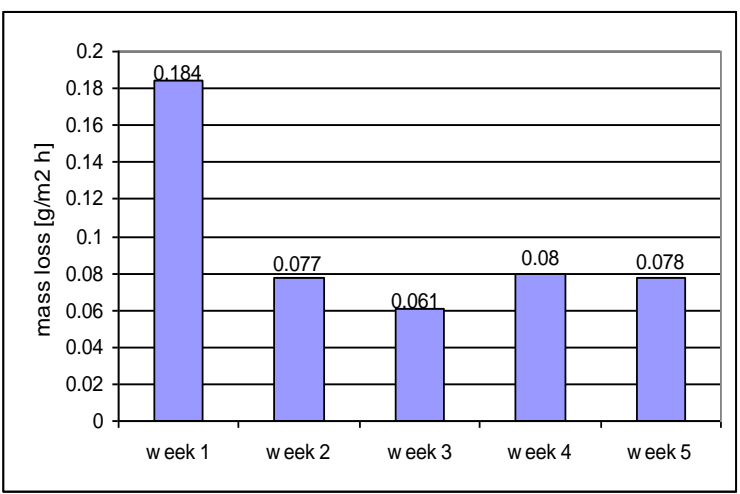

Fig. 4. Weekly mass loss in rainwater

\subsection{Behaviour of galvanized sheet in domestic water}

Domestic water was collected from a household. The solution presented, after settling the impurities, a $\mathrm{pH}$ of 6.56 .

Figures 5 and 6 show the mass loss depending on the duration of the corrosion process in this corrosive environment, respectively, the weekly mass loss.

It is found that the galvanized sheet is progressively corroded over time in domestic water and the highest corrosion rate is observed in week 4.

\subsection{Behaviour of galvanized sheet in sea water}

Sea water was prepared in the laboratory by dissolving $3 \%$ sodium chloride, chemically reactive, 
THE ANNALS OF "DUNAREA DE JOS" UNIVERSITY OF GALATI

FASCICLE IX. METALLURGY AND MATERIALS SCIENCE

No. 2 - 2020, ISSN 2668-4748; e-ISSN 2668-4756

Article DOI: $\underline{\text { https://doi.org/10.35219/mms.2020.2.06 }}$

in distilled water. The obtained solution had a $\mathrm{pH}$ of

9.18. The test results are shown in Figures 7 and 8.
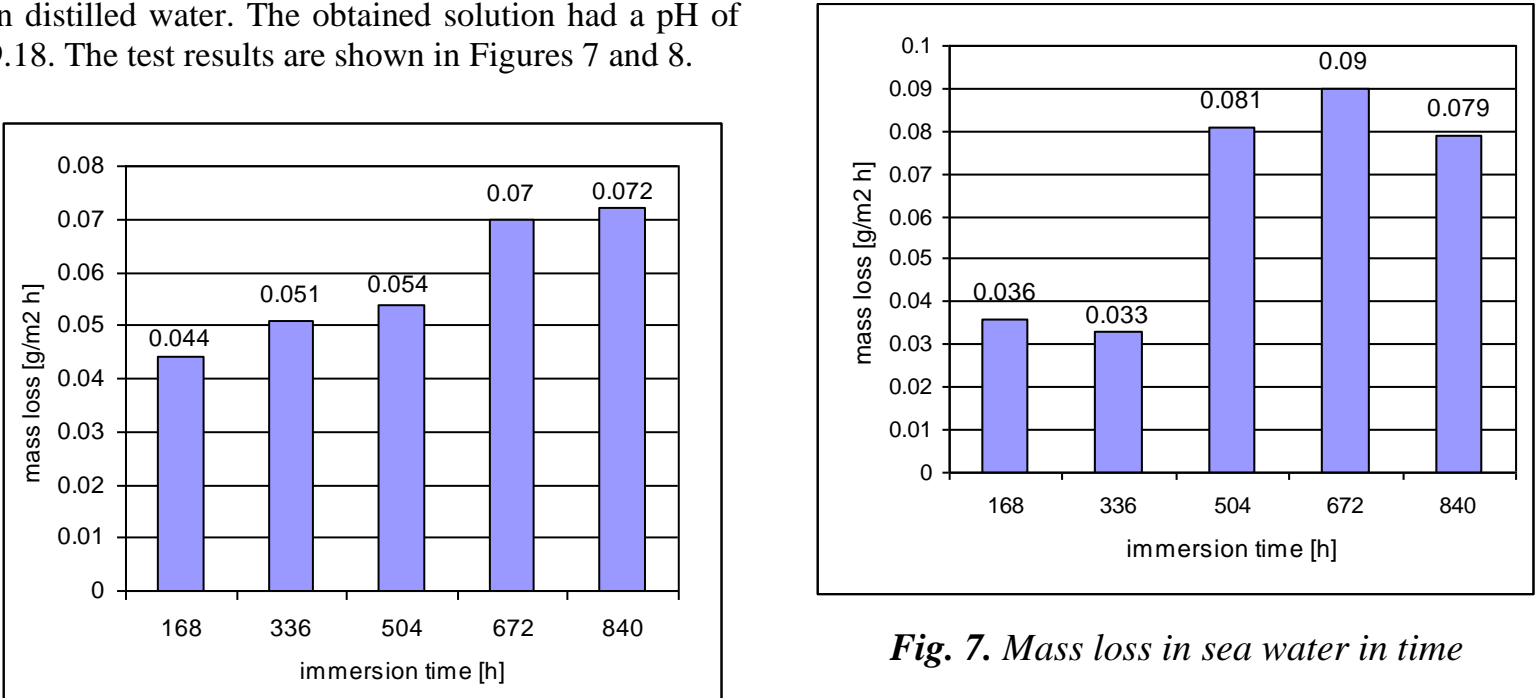

Fig. 7. Mass loss in sea water in time

Fig. 5. Mass loss in domestic water in time
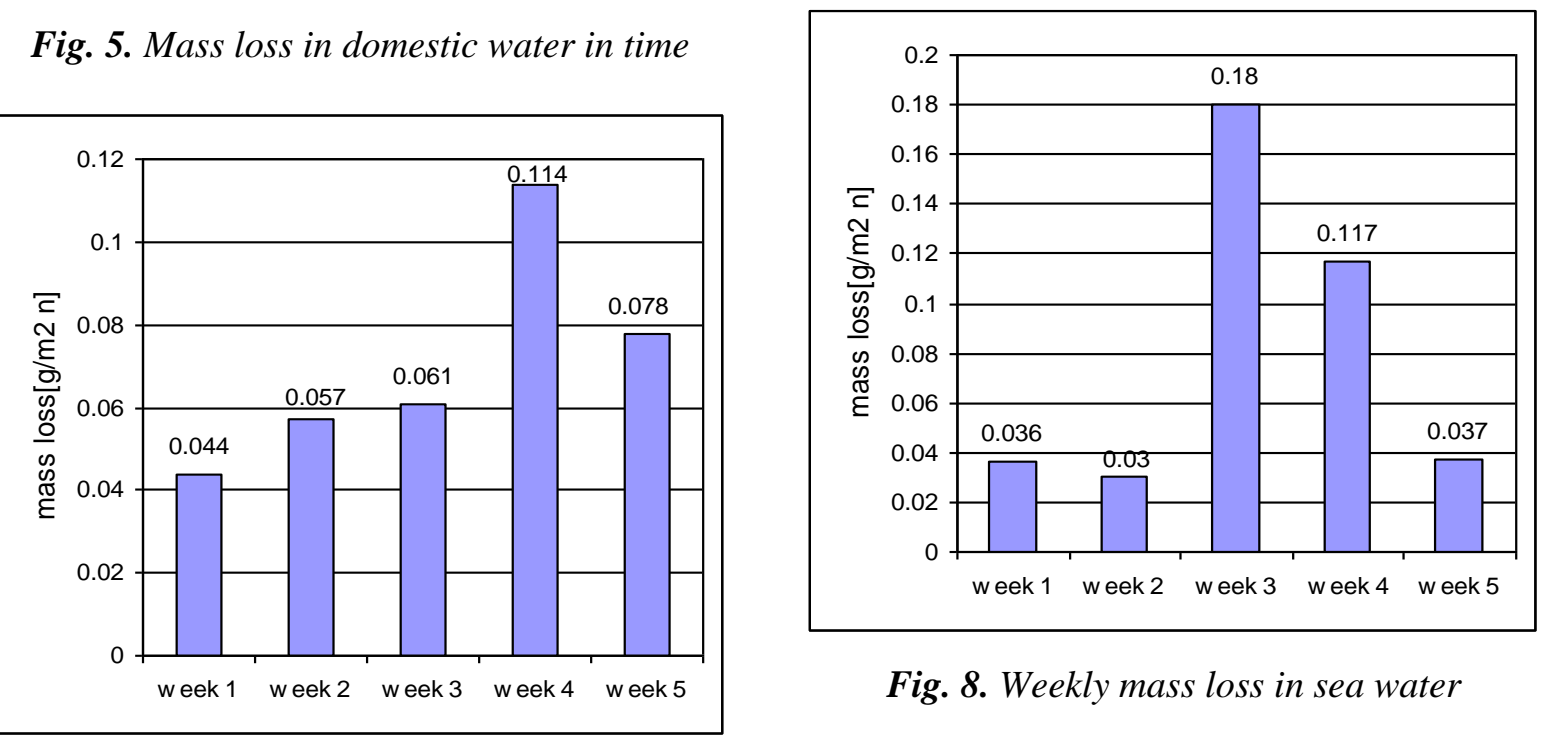

Fig. 8. Weekly mass loss in sea water

Fig. 6. Weekly mass loss in domestic water

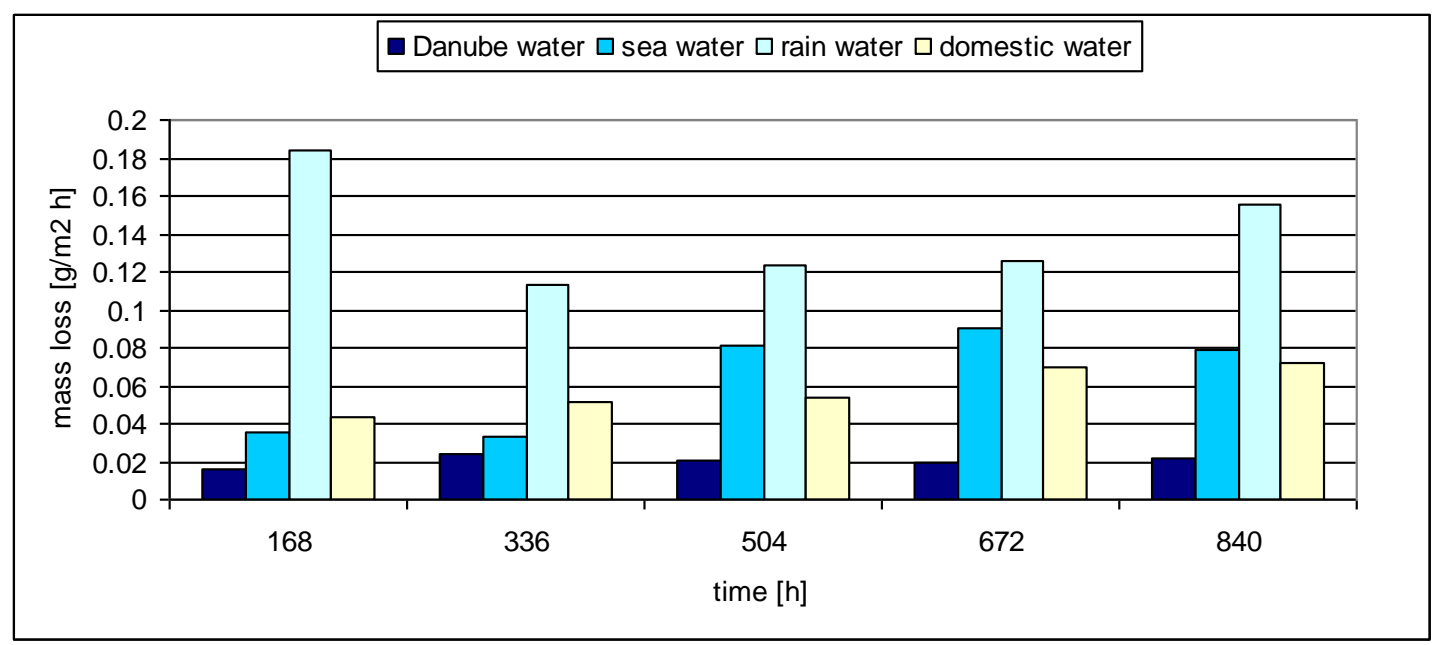

Fig. 9. Comparatively, the mass loss over time, in the four corrosion environments tested 


\section{THE ANNALS OF "DUNAREA DE JOS” UNIVERSITY OF GALATI \\ FASCICLE IX. METALLURGY AND MATERIALS SCIENCE \\ $\mathrm{N}^{\circ} .2$ - 2020, ISSN 2668-4748; e-ISSN 2668-4756 \\ Article DOI: https://doi.org/10.35219/mms.2020.2.06}

As can be seen, the corrosion process becomes significant after 504 hours of attack (Fig. 7), the highest mass loss being recorded in week 3 (Fig. 8). The formation of corrosion products slows down the corrosion rate in week 5 .

Figure 9 shows, comparatively, the mass loss over time, in the four corrosion environments tested.

The best corrosion behaviour is observed in seawater and the weakest in rainwater. In Danube water and domestic water, the corrosion rate after 840 hours is comparable.

It is observed that in fresh water the corrosion rate of galvanized sheet is significantly higher than in sea water. It must be borne in mind that seawater was prepared containing only sodium chloride. The presence of other salts that are usually found in sea water can change the corrosion behaviour.

\section{Conclusions}

In Danube water a close value of the gravimeter index $\left(0.022 \mathrm{~g} / \mathrm{m}^{2} \mathrm{~h}\right)$ is observed during the experiment, except for the first week when the mass loss is lower $\left(0.016 \mathrm{~g} / \mathrm{m}^{2} \mathrm{~h}\right)$.

In the rainwater the highest corrosion rate is recorded in the first week (after $168 \mathrm{~h}$ ) when the weight loss is $0.184 \mathrm{~g} / \mathrm{m}^{2} \mathrm{~h}$.

In domestic water the galvanized sheet is progressively corroded over time, and the highest corrosion rate is observed after 840 hours, respectively $0.072 \mathrm{~g} / \mathrm{m}^{2} \mathrm{~h}$.
The best corrosion behaviour for the galvanized sheet is observed in sea water and the weakest in rainwater. In Danube water and domestic water, the corrosion rate after 840 hours is comparable.

These results are strictly valid for the corrosive environments tested and cannot be generalized.

\section{References}

[1]. ***, http://www.specificatii-tehnice.ro/tabla-zincata. [2]. Alexandru Alexa, Tamara Radu, Florentina Potecasu, Anisoara Ciocan, Influence of additional alloying elements on corrosion resistance of hot dip galvanised steels, doi: 10.4028/www.scientific.net/MSF.730-732.811, Materials Science Forum, Vol. 730-732, ISSN 0255-5476, p. 811-816, 2013.

[3]. ***, https://www.ct.upt.ro/studenti/cursuri/dubina/Curs_metal_ 11.pdf.

[4]. Florea Oprea, Tamara Radu, Florentina Ionescu, Mecanisme şi procese privind coroziunea materialelor metalice, Editura “Ştiințifică F. M. R.”, ISBN:973- 99126-5-6, 2000.

[5]. ***, https://www.bernardoecenarro.com/uploads/guias/pdf/ guia02/de/ingles_naranja_2_8.pdf.

[6]. ***, https://galvanizeit.org/hot-dip-galvanizing/how-longdoes-hdg-last/in-water/.

[7]. Tamara Radu, Stela Constantinescu, Lucica Balint, Materiale metalice rezistente la coroziune, Editura "Ştiinţifică F. M. R.” ISBN:973-8151-31-7, 2004.

[8]. ***, https://galvanizeit.org/knowledgebase/article/galvanizedsteel-submerged-in-water.

[9]. ***, http://www.nordicgalvanizers.com/Frontpage\%20links/ documents/Corrcat_000.pdf.

[10]. Tamara Radu, Anişoara Ciocan, Gina Genoveva Istrate, Corrosion behavior of zinc alloy layers, The Annals of "Dunarea de Jos" University of Galati. Fascicle IX. Metallurgy and Materials Science, nr. 2, ISSN 1453-083X. p. 40-45, 2014. 